\title{
The impacts of the COVID-19 outbreak on emergency department visits of surgical patients
}

\author{
B Beslen Göksoy, M.D., () Muhammed Tahir Akça, M.D., () Ömer Faruk İnanç, M.D.
}

Department of General Surgery, Şehit Prof. Dr. İlhan Varank Sancaktepe Training and Research Hospital, İstanbul-Turkey

\begin{abstract}
BACKGROUND: The novel Coronavirus Disease 2019 (COVID-19) formed the basis for emergency department visits. This study aims to evaluate the effects of the pandemic on emergency department visits of surgical patients.

METHODS: The hospital database records of general surgery patients who presented at the emergency department in the period of March 2020-May 2020 (pandemic period) and March 2019-May 2019 (non-pandemic period) were retrospectively analyzed and compared. The primary outcome of this study was the emergency department visit rate of patients requiring a general surgery consultation. Secondary outcomes of this study were patient complaints, diagnosis and treatments, treatment rejection rate, triage category data, the effects of age and gender, and the hospitalization rate.
\end{abstract}

RESULTS: In this study, 618 patients were included: 265 patients from the pandemic period and 353 patients from the non-pandemic period. The analysis and comparison revealed that during the pandemic period, the presentation rate of female patients was lower than that of male patients ( $45.5 \%$ vs. $55.5 \%$, respectively, $p=0.045)$. The triage category rates of patient visits to the hospital during the pandemic period were higher in yellow and red, and lower in green $(p<0.01)$. The incidence of a surgical pathology finding was higher during the pandemic period $(p=0.019)$. The incidence of diseases related to the gastrointestinal tract was higher during the pandemic period $(p=0.0 \mathrm{II})$. The rate of open surgery in the pandemic period was higher than that of the non-pandemic period $(80.5 \% \mathrm{vs.} 32.7 \%$, respectively; $\mathrm{p}<0.01$ ). The treatment rejection rate was also higher in the pandemic period compared with the non-pandemic period $(20 \%$ vs. $3.7 \%$, respectively; $p<0.0 I, r)$. In addition, the hospitalization period was shorter in the pandemic period $(p=0.021)$.

CONCLUSION: A $25 \%$ reduction in the number of surgical patient visits to the emergency department was observed during the COVID- 19 outbreak. The biggest decrease was seen in patients with a green triage code and female patients. It is significant to evaluate the effects of the pandemic on surgical patients visited the emergency department to manage the post-epidemic period and to prepare for possible future epidemic periods.

Keywords: COVID-19; emergency department visit; emergency surgery.

\section{INTRODUCTION}

Coronavirus Disease 2019 (COVID-19) stemming from severe acute respiratory syndrome coronavirus-2 (SARSCoV-2) was declared as a pandemic by the world health organization (WHO) on March II, 2020. ${ }^{[1]}$ After that, prevention of the spread of the pandemic has been the primary goal. A wide range of individual protection measures has been undertaken all over the world. Both the WHO and health authorities have made some recommendations (e.g., handwashing, avoiding crowded areas, paying attention to social distance and use of face masks) to protect members of the public in the face of this insidious disease transmitted through droplets and to reduce its spread. ${ }^{[2]}$

COVID- 19 affects all age groups; however, it progresses more severely in the elderly and individuals with additional diseases. ${ }^{[3]}$ Naturally, institutions providing health services, particularly emergency services, where the first contact with the patient is established, are the riskiest environment and healthcare

Cite this article as: Göksoy B, Akça MT, İnanç ÖF. The impacts of the COVID-19 outbreak on emergency department visits of surgical patients. Ulus Travma Acil Cerrahi Derg 2020;26:685-692.

Address for correspondence: Beslen Göksoy, M.D.

Şehit Prof. Dr. İlhan Varank Eğitim ve Araştırma Hastanesi, Genel Cerrahi Kliniği, İstanbul, Turkey

Tel: +90 216 - 6063300 E-mail: beslengoksoy@gmail.com

Ulus Travma Acil Cerrahi Derg 2020;26(5):685-692 DOI: 10.14744/tjtes.2020.67927 Submitted: 13.07.2020 Accepted: 25.08.2020 Online: II.09.2020

Copyright 2020 Turkish Association of Trauma and Emergency Surgery 
personnel is the most likely to become infected during the period of infectivity. The behavior of the patient population that visits the emergency department, which is a significant element of healthcare, is affected by external changes that arise from natural disasters and pandemics. For example, previous studies have shown that a pandemic of the severe acute respiratory syndrome (SARS) directly affected the visits of patients in emergency departments. ${ }^{[4,5]}$

According to the official data of the Turkish Ministry of Health, the first COVID-19 case in Turkey was recorded on March II, 2020, and the first death was reported on March $17,2020 .{ }^{6]}$ During the early period of the pandemic, emergency departments in Turkey and all over the world focused on COVID-19. Recommendations for compliance with social distancing and quarantine rules made by local administrations and developing an understanding of the severity of the disease caused some public anxiety and affected hospital visits, especially to emergency departments. Less urgent conditions (e.g., acute cholecystitis and perianal area diseases), and patients requiring urgent intervention, such as trauma and acute abdomen are among, the most crucial reasons for emergency department visits. Postponing the appointments of the patients due to the COVID-19 outbreak may put patients who require urgent surgery at a higher risk of morbidity and mortality. Understanding the impacts of adjourned applications due to pandemic can help improve treatment strategies and health systems in future outbreaks.

The present study aims to evaluate the effects of the COVID-19 outbreak on surgical patients who presented at an emergency department of a pandemic hospital.

\section{MATERIALS AND METHODS}

\section{Study Design and Population}

This was a retrospective, observational study. This study was conducted in a tertiary healthcare institution with a380-bed capacity, where an average of 700,000 patient visits is seen every year at the emergency department. The study parameters were evaluated in two periods: the pandemic period and the non-pandemic period. The pandemic period studied comprised two months from the date when the hospital was declared a pandemic hospital, and the first case of COVID- 19 was seen: i.e., March I5, 2020-May I5, 2020. The non- pandemic period used was the same interval in the previous year: March 15, 2019-May 15, 2019. The hospital computer database records of patients who visited the emergency department and were consulted to general surgery between the dates specified were retrospectively analyzed (records during the pandemic period were prospectively maintained). The standard triage classification using three color-coded categories of green, signifying not urgent; yellow, indicating an urgent need; and red, designating the very urgent cases was implemented. ${ }^{[7]}$
Treatment rejection was defined as patients who were not administered any treatment because they did not accept the recommended medical or surgical treatment and/or hospitalization and left the hospital voluntarily. An elderly category was used to define and evaluate patients aged 65 years or more. The admission complaints of the patients were evaluated under six main headings: gastrointestinal system, perianal region, breast, inguinal region, exposure to trauma, and other complaints. The diagnoses of the patients were assessed using seven categories: non-surgical pathology, hepatobiliary system diseases, gastrointestinal system diseases, hernia, breast diseases, benign perianal area diseases, and other. Patients without a surgical pathology finding were defined as patients who did not receive any treatment.

The patients who received treatment were divided into two categories: outpatient treatment (oral antibiotic and/or analgesic treatment) and inpatient treatment (medical treatment or surgery). Inclusion criteria for both study periods included patients over the age of 18 who visited the emergency department and were consulted to general surgery. Patients under the age of 18 and patients who were consulted to general surgery during their follow-up (other than trauma) were excluded from this study. This study was approved by the Ethics Committee of Süreyyapaşa Chest Diseases and Chest Surgery Training and Research Hospital (Protocol number: I 16.2017.166).

\section{Outcomes}

The primary outcome of this study was the emergency department presentation rate of patients requiring a general surgery consultation. Secondary outcomes were the proportion of patients who underwent emergency surgery and received medical treatment, the patient admission complaints, the diagnoses and treatments, the treatment rejection rate, triage categories, the effects of age and gender on emergency admission, and the hospitalization rate. The rate of patients who were not found to have a general surgical pathology but who were hospitalized or transferred to other branches was also examined. The outcome criteria for the two periods were compared. In addition, a subgroup analysis was conducted to further examine patients who presented during the pandemic period to assess the impacts of the patients who were infected with COVID-19 at the time of admission or after admission (during inpatient treatment), and patients whose visits were delayed due to fear of becoming infected with COVID-19 virus.

\section{Statistical Analysis}

In addition to descriptive statistical methods (mean, SD, median, frequency, ratio, minimum, maximum), the Student's t-test was used for the comparison of two groups of variables with normal distribution, and the Mann-Whitney $U$ test was employed in 2-group comparisons of variables 
with non-normal distribution (e.g., age and length of hospital stay). The Pearson chi-square test and Fisher's exact test were used to comparing qualitative data (e.g., the patient admission complaints and diagnoses). Statistical significance was determined at $p<0.05$. NCSS 2007 software (NCSS, LLC, Kaysville, UT, USA) was used for the statistical analysis.

\section{RESULTS}

This study was conducted with 618 patients (265 patients in the pandemic period, and 353 patients in the non-pandemic period). The mean age of the patients was $46.20 \pm 19.42$ years. The number of visits to the emergency department of surgical patients during the pandemic and non-pandemic periods is shown in Figure I. The comparison revealed some differences. The rate of male patients who went to the hospital during the pandemic period was greater than females $(55.5 \%$ vs. $45.5 \%$, respectively; $\mathrm{p}=0.045$ ) (Fig. 2). The rate of study patients with a yellow or red triage code increased during the pandemic period and there were fewer green-coded patients relative to the non-pandemic period $(p<0.01)$ (Fig. 3). The demographic data and triage categories of the patients are shown in Table I.

There was no statistically significant difference between the two periods according to admission complaints (Table 2). The incidence of a surgical pathology finding in patients in the pandemic period was higher than in the non-pandemic period $(p=0.019)$. The incidence of gastrointestinal system disease finding in patients in the pandemic period was higher than in the non-pandemic period $(\mathrm{p}=0.0 \mathrm{II})$. In this study, 14 patients were diagnosed with complicated acute appendicitis: nine $(64.2 \%)$ patients in the pandemic period and five patients $(35.8 \%)$ in the non-pandemic period. Details of the admission diagnoses are provided in Table 3.

The rate of open surgery during the pandemic period was higher than the non-pandemic period $(p<0.01)$. The rate of patients declining treatment was statistically significantly higher during the pandemic period than in the non-pandemic period $(p<0.01)$. Patients were also hospitalized for a shorter-term during the pandemic period when compared with the non-pandemic period $(\mathrm{p}=0.02 \mathrm{I})$ (Table 4).

A general surgical pathology finding was not detected in 24 patients $(3.9 \%)(n=22$ in the pandemic period, and $n=2$ in the non-pandemic period), but they were hospitalized or referred to other branches.

\section{Subgroup Analysis}

During the pandemic period, 12 (4.5\%) patients stated that they had delayed their arrival due to the fear of becoming infected with the COVID-19 virus. Surgical pathology was detected in II patients (91.6\%) $(n=10$ acute appendicitis, and

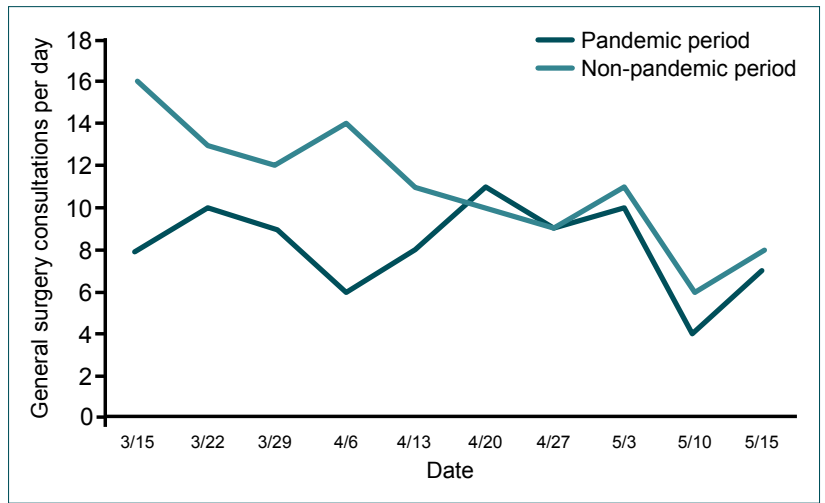

Figure 1. Daily patient visits to the emergency department requiring general surgery consultation from March 15 to May 15 for the years 2019 to 2020 .

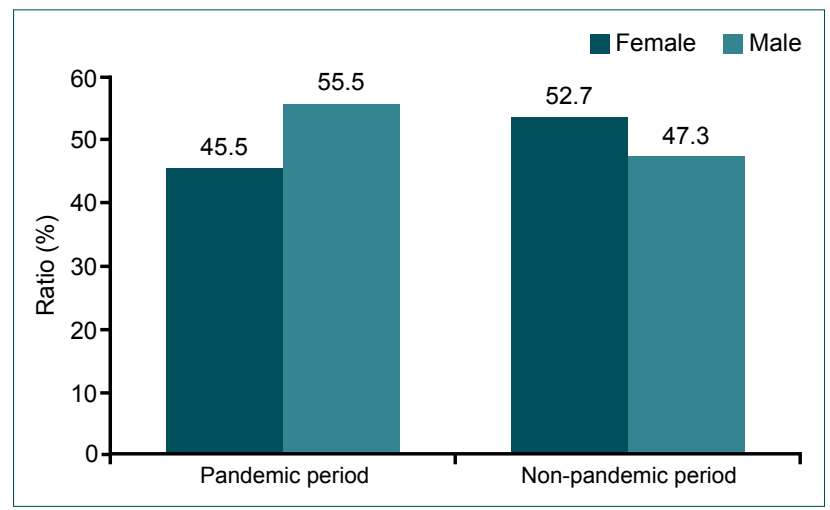

Figure 2. Distribution of the pandemic and non-pandemic period by sex.

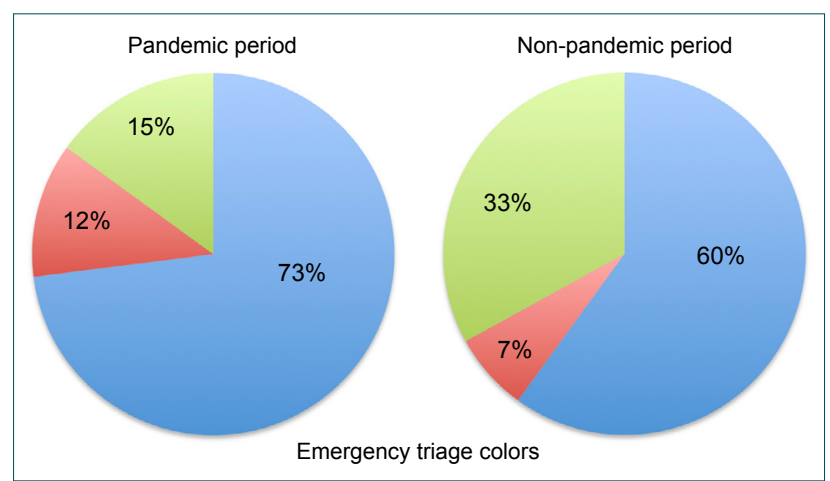

Figure 3. Distribution of the triage categories by the pandemic and non-pandemic period.

$\mathrm{n}=\mathrm{I}$ acute cholecystitis) who had deferred their treatment. Seven of the patients diagnosed with acute appendicitis were cases of complicated acute appendicitis.

COVID- I 9 infection was detected in II (4. I\%) of the patients during the pandemic period $(n=10$ at the time of admission, $\mathrm{n}=\mathrm{I}$ after admission). The mean length of the hospital stay of the patients with the COVID-19 infection was longer than that of those without $(6.43 \pm 3.21$ days and $2.68 \pm 1.92$ days, respectively; $\mathrm{p}<0.01$ ). 
Table I. Demographic characteristics and triage categories

\begin{tabular}{|c|c|c|c|c|}
\hline & $\begin{array}{c}\text { Non-pandemic period } \\
\qquad(n=353)\end{array}$ & $\begin{array}{l}\text { Pandemic period } \\
(n=265)\end{array}$ & $\begin{array}{c}\text { Total } \\
(n=618)\end{array}$ & $\mathbf{p}$ \\
\hline Age (years), mean $\pm S D$ & $46.20 \pm 19.42$ & $44.83 \pm 19.28$ & $46.20 \pm 19.42$ & ${ }^{\mathrm{a}} 0.385$ \\
\hline$<65, \mathrm{n}(\%)$ & $277(78.5)$ & $213(80.4)$ & $490(79.3)$ & ${ }^{b} 0.563$ \\
\hline$\geq 65, \mathrm{n}(\%)$ & $76(21.5)$ & $52(19.6)$ & $128(20.7)$ & \\
\hline \multicolumn{5}{|l|}{ Sex, n (\%) } \\
\hline Female & $186(52.7)$ & II 8 (45.5) & $304(49.2)$ & ${ }^{\circ} 0.045^{*}$ \\
\hline Male & $167(47.3)$ & 147 (55.5) & $314(50.8)$ & \\
\hline Triage category, n (\%) & & & & ${ }^{b} 0.001^{*}$ \\
\hline Green & $117(33.1)$ & $40(15.1)$ & 157 (25.4) & \\
\hline Yellow & $212(60.1)$ & $193(72.8)$ & $405(65.5)$ & \\
\hline Red & $24(6.8)$ & $32(12.1)$ & $56(9.1)$ & \\
\hline
\end{tabular}

SD: Standard deviation. ${ }^{a}$ Student's t-test; ${ }^{\text {Pearson }}$ Chi-Square Test; $* \mathrm{P}<0.05 ; * * \mathrm{P}<0.01$.

Table 2. Patient admission complaints presenting to the emergency department

\begin{tabular}{|c|c|c|c|c|}
\hline Patient complaints & $\begin{array}{c}\text { Non-pandemic period } \\
(\mathrm{n}=353)\end{array}$ & $\begin{array}{l}\text { Pandemic period } \\
(n=265)\end{array}$ & $\begin{array}{c}\text { Total } \\
(n=618)\end{array}$ & $\mathbf{p}$ \\
\hline Gastrointestinal complaints & $244(69.1)$ & $187(70.6)$ & 431 (69.7) & b0.699 \\
\hline Only abdominal pain & $205(58)$ & $142(53.6)$ & $347(56.1)$ & \\
\hline Abdominal pain and nausea/vomiting & II (3.I) & $20(7.5)$ & $31(5)$ & \\
\hline Abdominal pain and diarrhea & $9(2.5)$ & $7(2.6)$ & $16(2.6)$ & \\
\hline tOther & $19(5.4)$ & $18(6.8)$ & $37(6)$ & \\
\hline Groin pain & $24(6.8)$ & $9(3.4)$ & $33(5.3)$ & b0.063 \\
\hline Perianal region & $34(9.6)$ & $29(10.9)$ & $63(10.2)$ & '0.594 \\
\hline Only anorectal pain & $16(4.5)$ & $22(8.3)$ & $38(6.1)$ & \\
\hline Only rectal bleeding & $13(3.7)$ & $7(2.6)$ & $20(3.2)$ & \\
\hline Anorectal pain and bleeding & $5(1.4)$ & $0(0.0)$ & $5(0.8)$ & \\
\hline Breast pain & $8(2.3)$ & $4(1.5)$ & $12(1.9)$ & b 0.500 \\
\hline Trauma & $31(8.8)$ & $23(8.7)$ & $54(8.7)$ & ${ }^{b} 0.964$ \\
\hline Road traffic accident & $12(3.4)$ & II (4.5) & $23(3.7)$ & \\
\hline Firearm injuries & $5(1.4)$ & $2(0.7)$ & $7(1.1)$ & \\
\hline Sharp instrument injuries & $7(2)$ & $3(1.1)$ & $10(1.6)$ & \\
\hline ¥Other & $7(2)$ & $7(2.6)$ & $14(2.3)$ & \\
\hline §Other & $12(3.4)$ & $13(4.9)$ & $25(4.0)$ & '0.347 \\
\hline
\end{tabular}

tOther included abdominal pain and constipation, only constipation, abdominal pain and fever, only nausea-vomiting. ${ }^{\ddagger}$ Other included fall from a high level, accidental fall of an object, assault and battery, electric shock, burn wounds and foreign body swallowing. ${ }^{5}$ Other included armpit swelling, nail pain, backache, wound discharge, bloody emesis, respiratory distress, fainting. ${ }^{\text {PPearson }}$ Chi-Square Test; $* \mathrm{P}<0.05$.

\section{DISCUSSION}

In this study, we found a reduction in the number of general surgery patients admitted to the emergency department during the COVID-19 pandemic period compared with the non-pandemic period. The greatest decrease in triage categories was observed in green-coded patients, and gender comparison revealed that the number of female patients seen decreased significantly. In the pandemic period, the rate of detection of a surgical pathology was higher. The most prominent difference in diagnosis was seen in diseases of the gastrointestinal tract, and the incidence increased significantly during the pandemic period. In addition, we found that the rate of open surgery increased during the pandemic period. 
Table 3. Patient admission diagnoses in the emergency department

\begin{tabular}{|c|c|c|c|c|}
\hline Disease diagnoses & $\begin{array}{l}\text { Non-pandemic period } \\
\qquad(n=353)\end{array}$ & $\begin{array}{l}\text { Pandemic period } \\
(n=265)\end{array}$ & $\begin{array}{c}\text { Total } \\
(n=618)\end{array}$ & $\mathbf{p}$ \\
\hline Non-surgical pathology & I0I (28.6) & $54(20.4)$ & $155(25.1)$ & '0.019* \\
\hline Hepatobiliary system diseases & $72(20.4)$ & $62(23.4)$ & I34 (2|.7) & b0.370 \\
\hline Acute cholecystitis & $22(6.2)$ & $21(7.9)$ & $43(7.0)$ & \\
\hline Acute biliary pancreatitis & $21(5.9)$ & $18(6.8)$ & $39(6.3)$ & \\
\hline Biliary colic & $18(5.1)$ & $10(3.8)$ & $28(4.5)$ & \\
\hline tOther & II (3.I) & $13(5)$ & $24(3.9)$ & \\
\hline Gastrointestinal system diseases & $82(23.2)$ & $86(32.5)$ & $168(27.2)$ & ${ }^{\mathrm{b}} 0.011^{*}$ \\
\hline${ }^{\ddagger}$ Acute appendicitis & $48(13.6)$ & $45(17)$ & $93(15)$ & \\
\hline lleus & $13(3.7)$ & $15(5.7)$ & $28(4.5)$ & \\
\hline Gastroenteritis & $9(2.5)$ & $10(3.8)$ & $19(3.1)$ & \\
\hline Sigmoid diverticulitis & $7(2)$ & $10(3.8)$ & $17(2.8)$ & \\
\hline §Other & $5(1.4)$ & $6(2.2)$ & II (I7.8) & \\
\hline Hernia & $23(6.5)$ & $12(4.5)$ & $35(5.7)$ & b0.290 \\
\hline Non-strangulated inguinal hernia & $12(3.4)$ & $6(2.3)$ & $18(2.9)$ & \\
\hline Non-strangulated umbilical hernia & $6(1.7)$ & $2(0.8)$ & $8(1.3)$ & \\
\hline${ }^{\psi}$ Other & $6(1.7)$ & $4(1.5)$ & $9(1.4)$ & \\
\hline Breast diseases & $6(1.7)$ & $3(1.1)$ & $9(1.5)$ & ${ }^{b} 0.560$ \\
\hline Mastitis & $4(1.1)$ & I (0.4) & $5(0.8)$ & \\
\hline Breast abscess & $2(0.6)$ & $2(0.8)$ & $4(0.6)$ & \\
\hline Benign perianal area diseases & $31(8.8)$ & $23(8.7)$ & $54(8.7)$ & ${ }^{b} 0.964$ \\
\hline Haemorrhoids & $16(4.5)$ & $8(3)$ & $24(3.9)$ & \\
\hline Perianal abscess & $8(2.3)$ & $4(1.5)$ & $12(1.9)$ & \\
\hline Acute pilonidal abscess & $5(1.4)$ & $8(3)$ & $13(2.1)$ & \\
\hline TOther & $2(0.6)$ & $3(1.1)$ & $5(0.8)$ & \\
\hline${ }^{\epsilon}$ Other diagnosis & $38(10.8)$ & $25(9.4)$ & $63(10.2)$ & b 0.588 \\
\hline
\end{tabular}

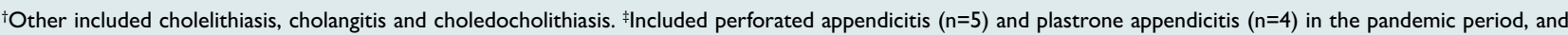
perforated appendicitis $(n=3)$ and plastrone appendicitis $(n=2)$ in the non-pandemic period. §Other included peptic ulcer perforation and bleeding, and diverticular bleeding. Other included strangulated inguinal hernia, strangulated umbilical hernia, strangulated incisional hernia, non-strangulated incisional hernia. ๆOther included anal fissure, gluteal abscess. ${ }^{€}$ Other included burn wounds, epiploic appendicitis, subcutaneous abscess-hematoma, mesenteric volvulus-panniculitis, rectus sheath hematoma, intra-abdominal abscess, solid organ injury, onychocryptosis, intramural hematoma of the duodenum, metastatic cancers, surgical site infection and sebaceous cyst. 'Pearson Chi-Square Test; ${ }^{*} \mathrm{P}<0.05$.

In the event of disasters, such as earthquakes, severe storms, and forest fires, emergency department visits, primarily those patients requiring surgery, tend to increase. ${ }^{[8-10]}$ The situation is different in the presence of epidemic disease. Striking examples were seen during the SARS epidemic period when the rate of emergency department visits decreased by $40 \%$ to $51.6 \%{ }^{[5,11,12]}$ In a recent study conducted in Portugal, it was found that the total incidence of emergency department visits within a month period (March 2020) during the COVID- 19 outbreak decreased $48 \%$, and the greatest decrease $(50 \%)$ was patients in the yellow-coded triage category. ${ }^{[13]}$

In our study, we detected a $25 \%$ reduction in the emergency presentations of general surgery patients during the pandemic period. Analysis of Figure I reveals that the biggest decrease occurred in the first 30 days of the pandemic, and particularly the first two weeks of April when the pandemic was the most intense. After the second week of April, the presentation rate approached that of the non-pandemic period. A decrease was observed in all of the triage categories during the pandemic period, notably the green-coded patients (from 33\% tol5\%). The proportion of yellow- and red-coded patients increased, and that of patients without a surgical pathology decreased. There are several possible reasons for the reduction in the number of non-emergency patient admissions we observed. First, patients were reluctant to go to the hospital due to the risk of infection. A second reason is related to the quarantine decisions made by local governments to prevent the spread of the virus. Patients also chose alternative means of treatment, such as home care, and going to other hospitals they thought 
Table 4. Comparison of the treatments by periods

\begin{tabular}{|c|c|c|c|c|}
\hline & $\begin{array}{c}\text { Pandemic period } \\
\text { n (\%) }\end{array}$ & $\begin{array}{c}\text { Non-pandemic period } \\
n(\%)\end{array}$ & $\begin{array}{l}\text { Total } \\
\text { n (\%) }\end{array}$ & $\mathbf{p}$ \\
\hline Total treatment & $157(59.2)$ & $247(70.0)$ & $404(65.4)$ & ${ }^{\circ} 0.006^{*}$ \\
\hline \multicolumn{5}{|l|}{ Treatment type } \\
\hline Outpatient treatment & $73(46.5)$ & I2I (49.0) & $194(48.0)$ & 0.625 \\
\hline \multirow[t]{2}{*}{ Inpatient treatment } & $84(53.5)$ & $126(51.0)$ & $210(52.0)$ & \\
\hline & 84 & 126 & 210 & \\
\hline Medical & $43(51.2)$ & $77(61.1)$ & $120(57.1)$ & '0.155 \\
\hline \multirow[t]{2}{*}{ Surgical } & $41(48.8)$ & 49 (38.9) & $90(42.9)$ & \\
\hline & 41 & 49 & 90 & \\
\hline Open surgery & $33(80.5)$ & $16(32.7)$ & $49(54.4)$ & ${ }^{b} 0.001^{*}$ \\
\hline Laparoscopic surgery & $8(19.5)$ & $33(67.3)$ & $41(45.6)$ & \\
\hline Declining the treatment & $53(20.0)$ & $13(3.7)$ & $66(10.7)$ & ${ }^{\mathrm{b}} 0.001^{* *}$ \\
\hline Length of hospital stay (day, Mean \pm SD) & $2.99 \pm 2.28$ & $4.00 \pm 3.27$ & $3.60 \pm 2.95$ & ${ }^{c} 0.021^{*}$ \\
\hline
\end{tabular}

SD: Standard deviation. ${ }^{b}$ Pearson Chi-Square Test; ${ }^{C}$ Mann-Whitney U Test. " $\mathrm{P}<0.05$. " $\mathrm{P}<0.01$.

to be less risky. Finally, news in social media indicating the increasing rate of infection among healthcare professionals added to anxiety among patients.

Despite strict quarantine rules (in Turkey, a curfew was imposed on people over the age of 65 on March 2I, 2020), a significant decrease in the proportion of patients older than 65 , and trauma patients were not seen.

In our study, the proportion of patients who had no surgical pathology result but were hospitalized in other branches was greater than that seen in the non-pandemic period. This suggests us that patients who presented at the emergency department during the pandemic period had more severe illnesses without any other alternatives for treatment.

In a study of 3009 patients that investigated the relationship between gender and pain, anxiety, and stress in emergency department visits, the findings showed that anxiety and stress were more frequently detected in female patients $(p<0.00 \mathrm{I})$. ${ }^{[14]}$ In our study, we observed that the number of female patients was slightly greater than that of male patients during the non-pandemic period. We found a significant decrease in female patients during the pandemic period. This may be related to the risk of infection during the pandemic and increased anxiety and stress in female patients.

Generally, there is a decrease in trauma cases during disease outbreaks. ${ }^{[12]}$ In contrast to the literature, the lack of any decrease in trauma patients in our study may have been because not every trauma case (especially sports injuries, child trauma, and some traffic accidents) is consulted to general surgery. The findings of other branches of service need to be examined in more detail. The incidence of diseases related to the gastrointestinal tract, the category with the greatest difference in the diagnosis of patients, increased significantly during the pandemic period compared with the non-pandemic period (32.5\% vs. $23.2 \%$ ). The incidence of complicated acute appendicitis (perforated or plastron appendicitis) may have been higher during the pandemic period due to delayed admission or referrals to outpatient treatment at an initial visit. We found that the rate of cases with complicated acute appendicitis during the pandemic period was $64.2 \%$ and onethird were patients who stated that they had delayed presentation due to the pandemic outbreak.

The number and proportion of patients with gastrointestinal system diseases, such as gastroenteritis, ileus, and diverticulitis, increased during the pandemic period. Measures implemented by local governments (e.g., quarantine rules and curfews) and by some professional groups and businesses to support working at home, as well as social media alerts, have led to individuals spending most of their time at home to prevent contracting the disease and its spread. A more sedentary life and unbalanced diet may have contributed to the increase in diseases related to the gastrointestinal tract during the pandemic period.

Another remarkable result of this study is the $16.3 \%$ increase in the treatment rejection rate seen during the pandemic period. The addition of a section on the consent forms required before hospitalization or surgery notifying patients of the risk of COVID-19 infection and a restriction in the number of relatives who could accompany the patient due to strict infection rules are possible causes of the increase in the rejection rate. There was a surgical pathology finding in the majority of patients who stated that they had delayed presentation due to fear of infection with COVID-19, and about half of these 
patients declined treatment. Also, in these patients, $70 \%$ of the cases with acute appendicitis were complicated acute appendicitis. This result indicates that fear of the pandemic can affect patient morbidity. The effects of postponed admissions may be dramatic, especially in cases of diseases that require emergency treatment.

Although there are some suggestions of a preference for open surgery rather than a laparoscopic approach in surgical treatment related to COVID-19, the evidence is still insufficient. ${ }^{[15]}$ We observed that the open surgery rate increased significantly in the pandemic period compared with the non-pandemic period. Only one of the patients who underwent open appendectomy had a COVID-19 infection. The patient was hospitalized for five postoperative days and administered oral medical treatment consisting of azithromycin $(250 \mathrm{mg}$ tab four times a day), hydroxychloroquine ( $400 \mathrm{mg}$ tab twice a day), and oseltamivir ( $75 \mathrm{mg}$ tab twice a day). All patients with a surgical pathology finding in the pandemic period were evaluated preoperatively with computed tomography, and swabs were taken from the nasopharynx and oropharynx of the patients with suspected COVID-19 infection. All surgeries were performed as recommended in the literature (e.g., using protective equipment, avoiding smoke and aerosol exposure). ${ }^{[16]}$ Although there is insufficient evidence that open surgery is more reliable, there is a preference among surgeons and other operating room personnel due to anxiety and uncertainty.

Although there was no significant difference between the periods in the rate of inpatients, the duration of hospitalization was shorter during the pandemic period. The average length of the hospital stay of patients infected with COVID-19 during the pandemic period was longer than that of non-infected patients. Even when emergency surgical pathologies were resolved, treatment for infection caused a prolonged hospital stay in this group.

The results of this study have valuable implications. A significant reduction in emergency service presentations of approximately one-third of non-emergency patients (especially in the green-coded triage category) during the pandemic period is important because it allows attention to be directed to more urgent patients. Based on this, how many patients "do not really urgent" visit to the emergency departments in normal times? Is one of the questions that come to mind? There was a partial decrease in visits by patients evaluated in the yellow-coded triage category, which constitutes the majority of emergency presentations. Delayed treatment of these patients who have more urgent needs may lead to increased severity of disease and negative effects, including requiring urgent surgery, which causes an increased disease burden. This pandemic outbreak may lead to the emergence of new approaches in the treatment of some surgical diseases. We do not yet know whether these predictions will be correct. To better understand the current situation, we thought it would be interesting to evaluate the post-pandemic period, and we planned to conduct a study to compare the pandemic period and the post-pandemic period.

\section{Limitations}

The records that have been kept prospectively during the pandemic period are the strength of this study. This study has some limitations. First of all, this was a single-center study, and it may not be appropriate to make generalizations about other pandemic hospitals. Second, some patients who went to the emergency department may have left the hospital voluntarily without consulting general surgery or they were discharged by the emergency medicine physicians, given the risk of contamination. Finally, some patients may have gone to the emergency department of other hospitals they found less risky.

The COVID- 19 outbreak has led to a review of national health systems around the world. It is significant to evaluate the effects of the pandemic on surgical patients admitted to the emergency department in the post-pandemic period, which will assist with preparation for possible future outbreaks.

In conclusion, during the COVID-19 outbreak, we observed a $25 \%$ reduction in the emergency department visits of surgical patients. The most severe decline was seen in the green-coded triage group and in female patients. Understanding that hospitals are risky placesas in hospital-acquired infections may reduce unnecessary visits. However, individuals who require emergency surgery do not hesitate to present at the emergency department.

Ethics Committee Approval: Approved by the local ethics committee.

Peer-review: Internally peer-reviewed.

Authorship Contributions: Concept: B.G., Ö.F.i., M.T.; Design: B.G., Ö.FI., M.T.; Supervision: B.G.; Fundings: B.G.; Materials: B.G., Ö.Fi., M.T.; Data: B.G., Ö.F.I., M.T.; Analysis: B.G., Ö.F.I., M.T.; Literature search: B.G.; Writing: B.G., Ö.FI., M.T.; Critical revision: B.G., Ö.F.i., M.T.

Conflict of Interest: None declared.

Financial Disclosure: The authors declared that this study has received no financial support.

\section{REFERENCES}

1. World health Organization. WHO Director-General's opening remarks at the media briefing on COVID-19 - 11 March 2020. Available from: https://www.who.int/dg/speeches/detail/who-director-general-s-opening-remarks-at-the-media-briefing-on-covid-19---11-march-2020.

2. World health Organization. Coronavirus disease (COVID-19) advice for the public. Available from: https://www.who.int/emergencies/diseases/ novel-coronavirus-2019/advice-for-public.

3. Zhou F, Yu T, Du R, Fan G, Liu Y, Liu Z, et al. Clinical course and risk factors for mortality of adult inpatients with COVID-19 in Wuhan, Chi- 
na: a retrospective cohort study. Lancet 2020;395:1054-62. [CrossRef]

4. Chen WK, Cheng YC, Chung YT, Lin CC. The impact of the SARS outbreak on an urban emergency department in Taiwan. Med Care 2005;43:168-72. [CrossRef]

5. Huang HH, Yen DH, Kao WF, Wang LM, Huang CI, Lee CH. Declining emergency department visits and costs during the severe acute respiratory syndrome (SARS) outbreak. J Formos Med Assoc 2006;105:31-7.

6. T.C Sağlık Bakanlığ1 Korona Tablosu. Available from: https://covid19. saglik.gov.tr/

7. Brouns SHA, Mignot-Evers L, Derkx F, Lambooij SL, Dieleman JP, Haak HR. Performance of the Manchester triage system in older emergency department patients: a retrospective cohort study. BMC Emerg Med 2019;19:3. [CrossRef]

8. Stryckman B, Walsh L, Carr BG, Hupert N, Lurie N. Impact of Superstorm Sandy on Medicare Patients' Utilization of Hospitals and Emergency Departments. West J Emerg Med 2017;18:1035-41. [CrossRef]

9. Moitinho de Almeida M, Schlüter BS, van Loenhout JAF, Thapa SS, Kumar KC, Singh R, et al. Changes in patient admissions after the 2015 Earthquake: a tertiary hospital-based study in Kathmandu, Nepal. Sci Rep 2020;10:4956. [CrossRef]

10. Shusterman D, Kaplan JZ, Canabarro C. Immediate health effects of an urban wildfire. West J Med 1993;158:133-8.

11. Chen TA, Lai KH, Chang HT. Impact of a severe acute respiratory syndrome outbreak in the emergency department: an experience in Taiwan. Emerg Med J 2004;21:660-2. [CrossRef]

12. Man CY, Yeung RS, Chung JY, Cameron PA. Impact of SARS on an emergency department in Hong Kong. Emerg Med (Fremantle) 2003;15:418-22. [CrossRef]

13. Santana R, Sousa JS, Soares P, Lopes S, Boto P, Rocha JV. The Demand for Hospital Emergency Services: Trends during the First Month of COVID-19 Response. Port J Public Health 2020;38:30-6. [CrossRef]

14. Patel R, Biros MH, Moore J, Miner JR. Gender differences in patient-described pain, stress, and anxiety among patients undergoing treatment for painful conditions in the emergency department. Acad Emerg Med 2014;21:1478-84. [CrossRef]

15. Vigneswaran Y, Prachand VN, Posner MC, Matthews JB, Hussain M. What Is the Appropriate Use of Laparoscopy over Open Procedures in the Current COVID-19 Climate?. J Gastrointest Surg 2020;24:1686-91.

16. Gök AFK, Eryılmaz M, Ozmen MM, Alimoglu O, Ertekin C, Kurtoglu $\mathrm{MH}$. Recommendations for Trauma and Emergency General Surgery Practice During COVID-19 Pandemic. Ulus Travma Acil Cerrahi Derg 2020;26:335-42. [CrossRef]

\section{ORIJIINAL ÇALIŞMA - ÖZET}

\section{COVID-19 salgınının cerrahi hastaların acil servis başvuruları üzerine etkisi}

\section{Dr. Beslen Göksoy, Dr. Muhammed Tahir Akça, Dr. Ömer Faruk İnanç}

Şehit Prof. Dr. İhan Varank Eğitim ve Araştırma Hastanesi, Genel Cerrahi Kliniği, İstanbul

AMAÇ: Coronavirus Hastalığı 2019 (COVID-19) acil servis başvurularının temelini oluşturmuştur. Bu çalışma pandeminin acil servise başvuran genel cerrahi hastalarına etkisini değerlendirmeyi amaçlamaktadır.

GEREÇ VE YÖNTEM: Mart 2020-Mayıs 2020 (pandemi dönemi) ile Mart 2019-Mayıs 2019 (pandemi olmayan dönem) tarihleri arasında acil servise başvuran genel cerrahi hastalarının kayıtları hastane bilgisayar tabanlı veritabanından geriye dönük olarak incelendi. Birincil sonuç acil servis başvuru oranlarıdı. İkincil sonuçlar hastaların başvuru şikayetleri, tanı ve tedavileri, tedavi red oranları, triyaj kategorileri, yaş ve cinsiyetin acil servis başvuru oranlarına etkisi ve hastanede yatış oranlarıdır. Sonuçlar her iki dönemde karşılaştııılmıştır.

BULGULAR: Çalışma pandemi döneminde 265 hasta, pandemi olmayan dönemde 353 hasta olmak üzere toplam 618 hastayla yapıldı. Pandemi döneminde kadın hastaların başvuru oranı, erkek hastalara göre daha düşüktü (sırasıyla, \%45.5’e karşı \%55.5, $p=0.045)$. Pandemi döneminde hastaneye başvuran hastaların triyaj kategorilerinin sarı ve kırmızı olma oranı daha yüksek, yeşil olma oranı ise daha düşüktü $(p<0.01)$. Pandemi dönemindeki hastalarda cerrahi patoloji görülme oranı daha fazlaydı $(p=0.019)$. Pandemi döneminde tanısı gastrointestinal sistem hastalıkları olan hastaların oranı daha yüksekti $(\mathrm{p}=0.0 \mathrm{II})$. Pandemi döneminde açık ameliyat oranı pandemi olmayan döneme göre daha yüksekti (sırasıyla, \%80.5'e karşı \%32.7, p<0.0I). Tedavi red oranı pandemi döneminde pandemi olmayan döneme göre daha yüksekti (sırasıyla, \%20'ye karşı \%3.7, p<0.0I). Hastanede yatış süreleri pandemi döneminde daha düşüktü $(p=0.021)$.

TARTIŞMA: COVID-19 salgını sırasında cerrahi hastaların acil servis başvurularında \%25 oranında azalma saptandı. En büyük düşüş yeşil alan başvurularında ve kadın hasta başvurularında görüldü. Pandeminin acil servise başvuran cerrahi hastalar üzerindeki etkisini değerlendirmek hem salgın sonrası dönemde hem de olası gelecek salgın dönemlerine hazırlık açısından önemlidir.

Anahtar sözcükler: Acil cerrahi; acil servis başvuruları; COVID-19.

Ulus Travma Acil Cerrahi Derg 2020;26(5):685-692 doi: 10.14744/tjtes.2020.67927 